\title{
Have you ever thought of going into industry?
}

Does Britain do enough to ensure that the merits of industry as a career are presented to young people?

In the last year the feeble productivity performance of British industry has been brought to public attention with depressing frequency. The figures speak for themselves: in five years the productivity index has risen by only $13 \%$, the index of actual production by less than $2 \%$. As we have noted before, the academic world has been weighing in recently with its own remedies, generally aimed at improving the rather bad university/industry links at the postgraduate end of the spectrum. Raising the productive capacity of industry has also been the recent theme of Mr Fred Mulley, Secretary of State for Education and Science, who has been urging students to think more of industrial careers and less of academe or the civil service.

There are, of course, two fairly distinct routes by which graduates get into industry. One is by making a definite choice around the age of seventeen to pursue engineering at university. The other is by pursuing some other course at university which does not exclude the possibility of working in industry. But it is by no means obvious that the student of seventeen will have enough information available to him or herself to make a reasoned judgement on whether to go into engineering.

Ask any schoolteacher what causes a child to opt for engineering and the most likely answer is that family influences play a major part. Parents or uncles who are themselves engineers seem to be the examples which lead many young people into the profession themselves. In this respect, engineering runs parallel to farming and medicine. The next most common reason for going into engineering is the conspicuous presence of a potential employer, probably in the local town-though three years later the graduate may well have a different opinion about returning home, of course.

Both of these reasons are rather good ones with a high content of realism in them, but what of the student without engineering in the family and with no particular employment in mind? The claims of engineering are, in general, rather poorly represented to him or her. Quite rightly there is a strong insistence in schools on the pur- suit of mathematics, physics and chemistry, so few engineers are to be found amongst schoolteachers. Small wonder, then, that many pupils will have never seriously considered engineering as an option to be set against a 'science' course at university.

Obviously those who do choose to do science have a chance to enter industry in a variety of ways upon graduating. But their period at university is likely to be one in which they will hear that pay in industry is not as good as it could be, because industry does not prize its graduates. They will also hear that the prospects of a science-trained employee getting to the boardroom are decidedly inferior to those of, say, an accountant. And even if these statements are not universally true, few in the university science environment are in a position to, nor sometimes wish to, speak in defence of industry.

There are many ways in which the recruitment of scientists for industry and the recruitment of students into engineering deserve attention, but the greatest advance surely awaits the removal of the barriers which in most universities separate engineering students from science students. In many cases hardly a course is taken in common even though the subject matter, particularly in mathematics and physics, runs broadly parallel. If a physics department wishes to teach electronics it will call on a physicist to do so; if an electrical engineering department needs a course in solid state physics it will be taught by an electrical engineer. These tendencies are greatest in the older established universities. The result is often inferior teaching, and, worse, the erection of disciplinary barriers by students themselves.

In recent months there has been some fairly radical talk about the need for postgraduate training modelled on the (best) American institutions. These same institutions are offering undergraduates a diversity which is unmatched in Britain and which allows the student to delay the difficult specialisation decision as long as possible. Critics claim that this leads to academically lightweight graduates: it does on the other hand lead to a greater maturity in making decisions about careers. And who can say that in the United States industry has not profited from the flow of excellent graduates? 